ReVISTA de BIOLOGía TROPICAL

\title{
Effects of different forms of nitrogen on rhizosphere microbial community structure of Eichhornia crassipes (Pontederiaceae)
}

\author{
Minghui $\mathrm{Fu}^{1 *} \&$ Lijun Zheng ${ }^{2}$ \\ 1. Department of Bioengineering, Guangdong University of Technology, Guangzhou, PR China; mhfu@gdut.edu.cn \\ 2. Department of Bioengineering, Guangdong University of Technology, Guangzhou, PR China; \\ jimmylzheng@hotmail.com \\ * Correspondence
}

Received 17-II-2015. Corrected 20-VII-2015. Accepted 25-VIII-2015.

\begin{abstract}
Rhizosphere microbial communities are important for phytoremediation, plant nutrition, health and metabolism. Many factors, including plant species, $\mathrm{pH}$ and nutritional factors influence rhizosphere microbiology. In this study, we analysed the effects of different forms of nitrogen on the structures of rhizosphere microbial communities of $E$. crassipes. Using a conventional culture method with special media, bacteria, actinobacteria and molds were cultured. We found that the numbers of bacteria were largely similar across the three culture conditions, while the numbers of actinobacteria and molds from the rhizosphere of $E$. crassipes cultured in $\mathrm{NH}_{4} \mathrm{Cl}$ solution were two orders of magnitude higher than those from the rhizospheres of plants cultured in distilled water and $\mathrm{KNO}_{3}$ solution. Using a culture-independent method of polymerase chain reaction-denaturing gradient gel electrophoresis (PCR-DGGE) of 16S rDNA, we found that the form of nitrogen could influence the components of the rhizosphere microbial community. Pseudoxanthomonas, Enterobacter and Citrobacter were present in all of the samples cultured under the three different experimental conditions. The genus Reyranella was found only in samples cultured in $\mathrm{KNO}_{3}$ solution; Acinetobacter and Streptomyces were unique to samples cultured in $\mathrm{NH}_{4} \mathrm{Cl}$ solution, and Pseudomonas, Pseudacidovorax and Methylosinus were found only in samples cultured in distilled water. Pseudoxanthomonas and Acidovorax were the dominant genera in the rhizosphere microbial community of E. crassipes cultured in $\mathrm{KNO}_{3}$ solution, while Novosphingobium was the dominant genus in the sample cultured in a nitrogen-deficient medium. Our results provide a theoretical foundation for using E. crassipes as a phytoremediation plant and controlling the widespread distribution of E. crassipes around the world using principles of nutrient metabolism. Rev. Biol. Trop. 64 (1): 213-220. Epub 2016 March 01.
\end{abstract}

Key words: Eichhornia crassipes, nitrogen, rhizosphere microbial community, PCR-DGGE.

Eutrophication of water bodies is becoming an increasingly severe problem with current levels of industrial development and the increasing population worldwide. Phytoremediation is an effective solution to this problem. In phytoremediation of water, aquatic plants remediate eutrophic water, a process that relies not only on the absorption and utilisation of nutrients by plants (Fu et al., 2014) but also on their relationship with rhizosphere microbiology (Lu, Hu, Liang, \& Zhu, 2010; Tanaka et al., 2012). Rhizosphere microbial communities can decompose organic substances and denitrify nitrogenous compounds by the processes of ammoxidation, nitrification and denitrification and transform phosphorus compounds (Stottmeister et al., 2003; Lu et al., 2010). In this way, they play an important role in plant nutrition, plant metabolism, phytoremediation and plant health (Elsgaard, Petersen, \& Debosz, 2001; Filip, 2002). Many environmental factors can influence the structure of the rhizosphere microbial community, thereby affecting phytoremediation and the growth of aquatic plants (Chen \& Shu, 2008; Ma, Xiong, He, $\& \mathrm{Ma}, 2008)$. Thus, the extent to which these 
communities vary with various environmental factors is of considerable interest to plantmicrobial ecologists (Marschner, Crowley, \& Yang, 2004).

Eichhornia crassipes is an aquatic invasive plant, originated in South America and represents one of the most productive plants in the world (Aboul-Enein et al., 2011). It has become a serious weed in freshwater habitats in rivers, lakes and reservoirs in both tropical and warm temperate areas worldwide. Owing to its strong ability to assimilate nitrogen and phosphorus (Reddy, Agami, \& Tucker, 1989; 1990) and accumulate heavy metals (Deng, Ye, \& Wong, 2004; Caldelas, Iglesia-Turino, Araus, Bort, \& Febrero, 2009), it is useful in wastewater phytoremediation (Casabianca, Laugier, \& Posada, 1995; Lu, Fu, \& Yin, 2008; Chen, Chen, Wan, Weng, \& Huang, 2010). In this study, we analysed the structure of the rhizosphere microbial communities associated with $E$. crassipes cultured under different forms of nitrogen (1.8 $\mathrm{mM}$ ammonium, $1.8 \mathrm{mM}$ nitrate and nitrogen deficiency). Our results provide a theoretical foundation for using E. crassipes as a phytoremediation plant and controlling the widespread distribution of E. crassipes around the world using principles of nutrient metabolism.

\section{MATERIALS AND METHODS}

Culture: E. crassipes plants were collected from a lake from the Western part of Guangdong University of Technology, Guangzhou, China in fall (September). The plants were cultured in nutrient solution $(0.25 \mathrm{mM}$ $\mathrm{Ca}\left(\mathrm{NO}_{3}\right)_{2} \cdot 4 \mathrm{H}_{2} \mathrm{O}, 0.25 \mathrm{mM} \mathrm{KNO}{ }_{3}, 0.1 \mathrm{mM}$ $\mathrm{MgSO}_{4} \cdot 7 \mathrm{H}_{2} \mathrm{O}$ and $0.05 \mathrm{mM} \mathrm{KH} \mathrm{PO}_{4}$ ) for 20 days at $25{ }^{\circ} \mathrm{C}$ with $16 \mathrm{~h}$ of light $(2000 \mathrm{Lx})$ and $8 \mathrm{~h}$ of darkness indoors. The solution was replaced completely every two days. After preculture, the E. crassipes plants were cultured in either $1.8 \mathrm{mM} \mathrm{NH}_{4} \mathrm{Cl}$ solution, $1.8 \mathrm{mM} \mathrm{KNO}_{3}$ solution, or distilled water for two weeks under the same conditions as the preculture.
Sample preparation: The first 1-2 cm of root tips (90 g) of E. crassipes mixed with 90 $\mathrm{mL}$ sterile water and some glass beads were vortexed (2 $000 \mathrm{rpm})$ for $20 \mathrm{~min}$ and then allowed to rest for 20-30 s. The supernatant solution was collected. Some of it was stored in $-80{ }^{\circ} \mathrm{C}$ for DNA extraction and some was used as a sample solution which was diluted in 10 -fold steps with sterile water.

Determination of the number of culturable rhizosphere microbial communities: The densities of microbial communities in the plant rhizosphere were determined by a conventional culture method using the following media: salt beef extract tryptone medium for bacterial culture; Gao 1 synthetic medium for actinobacteria, with the addition of potassium dichromate $(100 \mu \mathrm{g} / \mathrm{mL})$ to inhibit bacteria and molds and salt Czapek Dox agar for mold culture. Diluted sample $(100 \mu \mathrm{L})$ was spread onto plates and cultured at $37^{\circ} \mathrm{C}$ for one or two days (for bacteria) or $28{ }^{\circ} \mathrm{C}$ for a week (for actinobacteria and molds). The number of clones in each type of culture medium was determined. Each solution was assayed in triplicate to obtain the average (Matsuzawai, Tanaka, Tamaki, Kamagata, \& Mori, 2010).

Extraction of DNA and PCR amplification: DNA was extracted from rhizosphere samples prepared as described above using a soil DNA extraction kit (Hangzhou Haoji Biotechnology Ltd.) according to the manufacturer's instructions. Two rounds of PCR amplification were performed with primers listed in Table 1. The primers for this procedure were designed from the V3 region of bacterial 16s rRNA. The conditions for the first amplification were $94{ }^{\circ} \mathrm{C}$ for $2 \mathrm{~min}, 35$ cycles $\left(94^{\circ} \mathrm{C}\right.$ for $30 \mathrm{~s}, 58^{\circ} \mathrm{C}$ for $30 \mathrm{~s}$ and $68^{\circ} \mathrm{C}$ for $1.5 \mathrm{~min}$ ). The conditions for the second amplification were 94 ${ }^{\circ} \mathrm{C}$ for $2 \mathrm{~min}, 30$ cycles $\left(94{ }^{\circ} \mathrm{C}\right.$ for $30 \mathrm{~s}, 55^{\circ} \mathrm{C}$ for $45 \mathrm{~s}$ and $68^{\circ} \mathrm{C}$ for $30 \mathrm{~s}$ ). PCR products were separated on $1 \%$ agarose/EtBr gel. Amplification experiments were performed in triplicate on every sample (Mota et al., 2008). 
TABLE 1

Primer sequences for PCR

\begin{tabular}{ll}
\multicolumn{1}{c}{ Primer name } & \multicolumn{1}{c}{ Primer sequences } \\
Bac-V3-F1 & 5-GAGTTTGATCCTGGCTCAG-3 \\
Bac-V3-R1 & 5-AGAAAGGAGGTGATCCAGCC-3 \\
Bac-V3-F2 & 5-CGCCCGCCGCGCGCGGCGGGCGGGGCGGGGGCACGGGGGG \\
Bac-V3-R2 & CCTACGGGAGGCAGCAG-3 \\
\hline
\end{tabular}

TABLE 2

The number of rhizosphere microbiology from Eichnornia crassipes cultured in three conditions (cfu/mL)

\begin{tabular}{lccc}
\multicolumn{1}{c}{ Kind of microbiology } & Distilled water & $\mathrm{KNO}_{3}$ solution & $\mathrm{NH}_{4} \mathrm{Cl}$ solution \\
Bacteria & $4.70 \times 10^{7}$ & $4.40 \times 10^{7}$ & $3.51 \times 10^{7}$ \\
Actinobacteria & $7.90 \times 10^{5}$ & $7.00 \times 10^{4}$ & $3.50 \times 10^{7}$ \\
Moulds & $7.00 \times 10^{3}$ & $4.00 \times 10^{3}$ & $1.29 \times 10^{6}$ \\
\hline
\end{tabular}

Denaturing gradient gel electrophoresis (DGGE) analysis of microbial rRNA genes: PCR products were purified with a purification kit (Hangzhou Haoji Biotechnology Ltd.) and then separated by DGGE using the Decode Universal Mutation Detection System (BioRad, USA) with a run time of $12 \mathrm{~h}$ in Trisacetate-EDTA buffer heated to $60{ }^{\circ} \mathrm{C}$. Bacterial 16s rRNA gene PCR products were electrophoresed in an acrylamide gel with a gradient of $35-60 \%$ denaturant. After electrophoresis, the gel was stained with SYBR Green I for $30 \mathrm{~min}$ and the bands were examined using the Gel Doc 2000 gel imaging system (Bio-Rad, USA).

Statistical analysis of DGGE image: The DGGE image was scanned with the Quantity One program and the intensity of every band was reported. The evenness and diversity indexes were compared by one-way analysis of variance and Tukey HSD test for post-hoc analysis using SPSS (13.0). Diversity was calculated as the Shannon index of diversity (H) to compare changes in diversity of microbial communities between the three treatments using the following function: $\mathrm{H}=-\sum\left(\mathrm{P}_{\mathrm{i}}\right) \log _{2} \mathrm{P}_{\mathrm{i}}$, where $P_{i}=n_{i} / N, n_{i}$ is the band intensity and $\mathrm{N}$ is the sum of all band intensities in the curve. Simpson's diversity index (D) for infinite populations is equal to 1 -sum $\left(\mathrm{P}_{\mathrm{i}} * \mathrm{P}_{\mathrm{i}}\right)$. The
DGGE evenness (E), a measure of how evenly DGGE bands are distributed in a given sample, is calculated as $\mathrm{E}=\mathrm{H} / \log _{2}(\mathrm{~S})$ where richness (S) refers to the number of bands detected in a given sample.

Sequencing and analysis of bright bands: Clear differential display or common display bands were cut out and redissolved in Tris buffer ( $\mathrm{pH} \mathrm{8.0)}$. The supernatant was subjected to PCR $\left(94{ }^{\circ} \mathrm{C}\right.$ for $2 \mathrm{~min}, 30$ cycles; each cycle included $94{ }^{\circ} \mathrm{C}$ for $30 \mathrm{~s}, 55^{\circ} \mathrm{C}$ for $45 \mathrm{~s}$ and $68^{\circ} \mathrm{C}$ for $30 \mathrm{~s}$ ) with the primers BacV3-F2 and Bac-V3-R2 (listed in Table 1). PCR products were recycled, cloned and sequenced. All sequences were blasted against the nonredundant nucleotide database in NCBI to identify the most similar sequences in the database (http://www.ncbi.nlm.nih.gov). These findings were used to classify of our sequences.

\section{RESULTS}

Determination of the total numbers of culturable bacteria, actinobacteria and molds: The numbers of rhizosphere bacteria, actinobacteria and molds are listed in Table 2. Under each culture condition, the numbers of bacteria were the highest, followed by actinobacteria, and less molds. The numbers of 
bacteria were largely similar across the three culture conditions, whereas the numbers of actinobacteria and molds from the rhizosphere of $E$. crassipes cultured in $\mathrm{NH}_{4} \mathrm{Cl}$ solution were two orders of magnitude higher than those from the rhizospheres of plants cultured in distilled water and $\mathrm{KNO}_{3}$ solution.

\section{PCR amplification of extracted DNA} and DGGE analysis: The results of electrophoresis of the second round of PCR products are shown in Fig. 1. There was only one 230 bp band in every lane (with each sample run in two lanes). All three samples from the DGGE results showed many clear bands (Fig. 2). The Shannon index of diversity (H), Simpson's diversity index (D) and the evenness (E) of every sample are listed in Table 3 . They indicate that all three samples had an abundance of diversity in the microbial community of the rhizosphere. But there was no significant difference (all $\mathrm{P}>0.05$ ) among the Shannon index of diversity $(\mathrm{H})$, among Simpson's

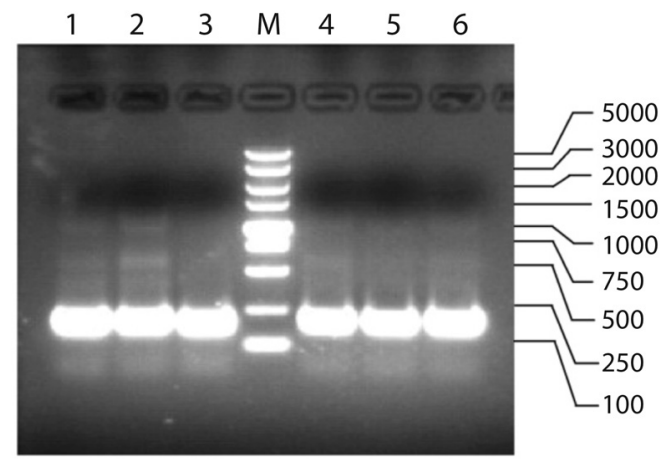

Fig. 1. Electrophoresis of the PCR products (lanes 1 and 2, samples cultured in $\mathrm{KNO}_{3}$ solution; $\mathrm{M}$, marker; lanes 3 and 4, samples cultured in $\mathrm{NH}_{4} \mathrm{Cl}$ solution; lanes 5 and 6 , samples cultured in distilled water). diversity index (D), or among the evenness (E) of three samples.

Sequence analysis: Clear differential display bands or clear common display bands were selected to be sequenced. The selected sequences were used for BLAST against the non-redundant nucleotide sequence database to search for the most similar sequences whose classifications were known. Among the eight sequences from the sample cultured in $\mathrm{KNO}_{3}$ solution, two were similar to sequences of Pseudoxanthomonas and two were similar to those of Acidovorax. The other four sequences were similar to those of Devosia, Novosphingobium, Enterobacter and Reyranella. Among

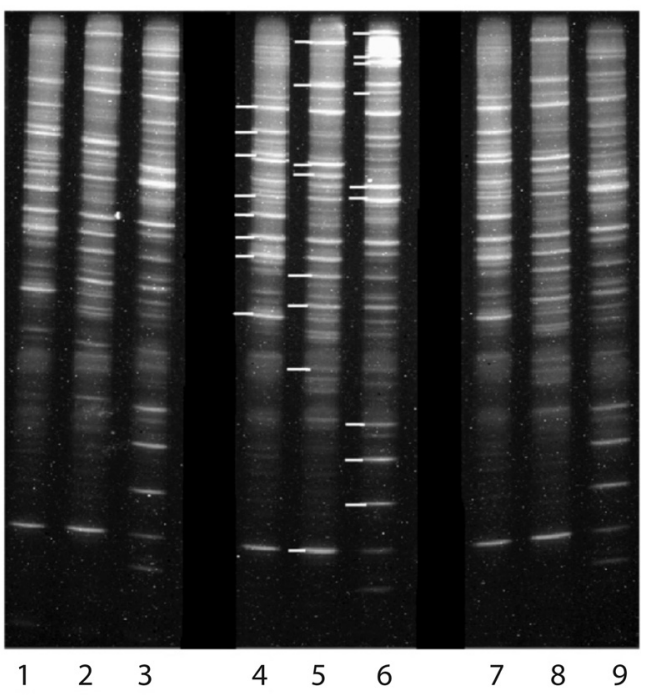

Fig. 2. Denaturing gradient gel electrophoresis result (lanes 1, 4, and 7, samples cultured in $\mathrm{KNO}_{3}$ solution; lanes 2, 5, and 8 , samples cultured in $\mathrm{NH}_{4} \mathrm{Cl}$ solution; lanes 3,6 , and 9 , samples cultured in distilled water). The short segment beside the lane indicates the bands that were sequenced.

TABLE 3

The Shannon index of diversity (H), Simpson's diversity index (D) and the evenness (E) of every sample

\begin{tabular}{cccc} 
Diversity indices & Distilled water & $\mathrm{KNO}_{3}$ solution & $\mathrm{NH}_{4} \mathrm{Cl}$ solution \\
$\mathrm{H}$ & $5.201 \pm 0.072$ & $5.293 \pm 0.016$ & $5.294 \pm 0.077$ \\
$\mathrm{D}$ & $0.968 \pm 0.003$ & $0.971 \pm 0.001$ & $0.972 \pm 0.001$ \\
$\mathrm{E}$ & $0.953 \pm 0.013$ & $0.954 \pm 0.010$ & $0.968 \pm 0.006$ \\
\hline
\end{tabular}

Mean \pm standard deviation (SD). 
the eight sequences from the sample cultured in $\mathrm{NH}_{4} \mathrm{Cl}$ solution, there were sequences similar to those of Acinetobacter, Flectobacillus, Cytophaga, Streptomyces, Devosia, Enterobacter, Rhizobium and Citrobacter, whereas among the nine sequences cultured in distilled water, there were three sequences similar to that of Novosphingobium and six sequences similar to those of Pseudomonas, Pseudacidovorax, Acidovorax, Brevundimonas, Rhodospirillum and Methylosinus. Pseudoxanthomonas, Enterobacter and Citrobacter were found in bands from all three samples. The genus Reyranella was found only in samples cultured in $\mathrm{KNO}_{3}$ solution; Acinetobacter and Streptomyces were unique to samples cultured in $\mathrm{NH}_{4} \mathrm{Cl}$ solution, and Pseudomonas, Pseudacidovorax and Methylosinus were found only in samples cultured in distilled water.

\section{DISCUSSION}

It has been previously reported that the diversity and abundance of different components of rhizosphere microbial communities were influenced by plant nutrition and other environmental factors. Hamonts et al. (2013) reported that nitrogen limitation significantly influenced the structure and function of denitrifier communities in the rhizosphere of wheat. An investigation by Marschner et al. (2004) showed that bacterial community structure was influenced by soil $\mathrm{pH}$ and type of phosphorus fertilisation. Söderberg and Bååth (2004) found that bacterial activity in the barley rhizosphere decreased when ammonium was added.

Our study also found that not only the numbers of culturable microbial communities but also the compositions of the microbial communities of E. crassipes were influenced by different forms of nitrogen. Although Pseudoxanthomonas, Enterobacter and Citrobacter were found in all three samples, different treatment samples had unique genera and dominant genera. Pseudoxanthomonas and Acidovorax were the dominant genera in the rhizosphere microbial community of E. crassipes cultured in $\mathrm{KNO}_{3}$ solution, whereas Novosphingobium was the dominant genus in the sample cultured in distilled water. The differences among the rhizosphere microbial communities were a response to environmental factors. Because individual components of the rhizosphere microbial community had different functions that allowed them to exploit specific environmental conditions. In the environment with plenty of ammonium, the special microbial communities of E. crassipes rhizosphere can effectively absorb or transform the ammonium; while in the environment with much nitrate, the microbial communities of rhizosphere will change into adapted compositions which can take in or transform the nitrate. Through all these microbial communities of rhizosphere, the nitrogen can be removed from water or transformed into other forms which can be utilized by other organisms. The study of the effects of various forms of nitrogen on these communities can provide a theoretical foundation for rhizosphere microbiology in phytoremediation, plant growth, plant protection and other areas. In the rhizosphere microbial community of E. crassipes, several bacterial species are common in soil and water. Some of them, including Acidovorax, Acinetobacter, Streptomyces, Enterobacter, Citrobacter, Novosphingobium and Pseudomonas, can decompose organic or macromolecular compounds. Some are nitrogen fixers, such as Rhizobium, Devosia, Pseudacidovorax and Rhodospirillum. Methylosinus is an example of a methanotroph. Many bacteria are very important in phytoremediation (Lu et al., 2010; Bai, Liang, Liu, Hu, \& Qu, 2014). But from the results of our study, we could not identify specific nitrifying or denitrifying bacteria in the $\mathrm{NH}_{4} \mathrm{Cl}$ or $\mathrm{KNO}_{3}$ treatment samples, probably because the removal of nitrogen in water with $\mathrm{NH}_{4} \mathrm{Cl}$ or $\mathrm{KNO}_{3}$ is a complex process that comprises not only nitrification and denitrification, but also absorption and use by bacteria and plants. Thus, nitrogen removal represents the integrated action of plants and bacteria in phytoremediation.

There are several likely reasons for the effects of different forms of nitrogen on 
rhizosphere microbial communities. First, the form of nitrogen present influences the $\mathrm{pH}$ of culture media (O'Donnell, Seasman, Macrae, Waite, \& Davies, 2001; Kemmitt, Wright, Goulding, \& Jones, 2006). Nitrogen in the form of ammonium decreases the $\mathrm{pH}$ of the soil, while nitrogen in the form of nitrate increases the $\mathrm{pH}$. Ma et al. (2008) reported that ammonium increased the numbers of actinobacteria and fungi in the rhizosphere of Yumai 49 (a medium-gluten wheat), and our study confirmed this result. The numbers of culturable actinobacteria and molds from the rhizosphere of $E$. crassipes cultured in $\mathrm{NH}_{4} \mathrm{Cl}$ solution were more than two orders of magnitude higher than those cultured from plants in distilled water or $\mathrm{KNO}_{3}$ solution. DGGE analysis also confirmed that $\mathrm{NH}_{4} \mathrm{Cl}$ can promote the growth of actinobacteria such as Streptomyces. We are aware that $\mathrm{NH}_{4} \mathrm{Cl}$ can reduce the $\mathrm{pH}$ of solutions. Molds prefer slight acidity and survive better in acidic solutions. In contrast, actinobacteria prefer slight alkalinity or neutrality ( $\mathrm{Su}$ et al., 2013), so the mechanism whereby $\mathrm{NH}_{4} \mathrm{Cl}$ improved the growth of actinobacteria was not pH-dependent.

Another reason why different forms of nitrogen influenced the rhizosphere microbial community is that the form of nitrogen present can directly affect the growth of the community. Because of various preferences for the type of nitrogen, the presence of different forms of nitrogen alters the components of the rhizosphere microbial community. The experiments of Zhu, Yao, Long, and Yang (2004) indicated that ammonium ion could inhibit the hyphal growth of AM fungus. Liu, Huang, and Kong (2005) also confirmed that Aspergillus niger ML2 and ML4 exhibited high efficiency of phosphate solubilisation when cultured in a medium with ammonium as the only nitrogen source.

The final reason why different forms of nitrogen can influence the rhizosphere microbial community is that different forms of nitrogen can differently influence the growth and development of plants, particularly roots (Gao \& Pan, 1998; Ma, Wang, Wang, \& Wang,
2004). The rhizosphere of plants provides a microenvironment for the growth of rhizosphere microbes. Respiration and other physiological processes of plant roots can affect this microenvironment. Rhizosphere microbiology is associated with the secretion and abscission of plant roots (Liljeroth, Bååth, Mathiasson, \& Lundborg, 1990), and different forms of nitrogen can influence these processes, thereby influencing the microbiology of the rhizosphere. Amino acids secreted from the roots of $E$. crassipes induced chemotaxis in its rhizosphere bacteria (Zhao \& Zheng, 1996). The root exudates from E. crassipes can stimulate the growth of phenol-degrading Enterobacter sp. nov (Wu \& Zheng, 1993). In our experiment, ammonium was found to stimulate the growth of actinobacteria; however, whether any secretion or abscission from the roots of $E$. crassipes can stimulate the growth of actinobacteria remains to be investigated.

\section{ACKNOWLEDGMENTS}

This work was funded by the National Science Foundation under grant 21177029, Science and Technology Innovation Program of Educational Commission of Guangdong Province of grant 2012KJCX0043.

\section{RESUMEN}

Comunidades microbianas de la rizósfera son importantes para la fitorremediación, nutrición vegetal, salud y metabolismo. Muchos factores, incluyendo la especie de planta, el pH y los factores nutricionales influyen en la microbiología de la rizósfera. En este estudio, se analizaron los efectos de las diferentes formas del nitrógeno en la estructura de las comunidades microbianas de la rizósfera de E. crassipes. Mediante métodos de cultivo convencional con medios especiales se cultivaron: bacterias, actinobacterias y mohos. Se encontró que el número de bacterias era en gran parte similar a través de las tres condiciones de cultivo, mientras que el número de actinobacterias y mohos de la rizósfera de E. crassipes cultivadas en solución de $\mathrm{NH} 4 \mathrm{Cl}$ era dos órdenes de magnitud superior a los de las rizósferas de plantas cultivadas en agua destilada y solución de KNO3. Utilizando un método de cultivo independiente de electroforesis en gel con gradiente de desnaturalización (PCR-DGGE) del ADNr 16S, se encontró que la forma de nitrógeno podría influir en los componentes de 
la comunidad microbiana de la rizósfera. Pseudoxanthomonas, Enterobacter y Citrobacter estaban presentes en todas las muestras cultivadas en las tres condiciones experimentales. El género Reyranella se encontró sólo en muestras cultivadas en solución de KNO3; Acinetobacter y Streptomyces eran las únicas muestras cultivadas en solución de NH4Cl, y Pseudomonas, Pseudacidovorax y Methylosinus se encontraron sólo en muestras cultivadas en agua destilada. Pseudoxanthomonas y Acidovorax eran los géneros dominantes en la comunidad microbiana de la rizósfera de E. crassipes cultivadas en solución de $\mathrm{KNO} 3$, mientras que Novos phingobium fue el género dominante en la muestra cultivada en un medio deficiente de nitrógeno. Nuestros resultados proporcionan una base teórica para el uso de $E$. crassipes como planta fitorremediadora y para controlar la distribución generalizada de E. crassipes en todo el mundo a través de los principios del metabolismo de nutrientes.

Palabras clave: Eichhornia crassipes, nitrógeno, comunidades microbianas de la rizósfera, PCR-DGGE.

\section{REFERENCES}

Aboul-Enein, A. M., Al-Abd, A. M., Shalaby, E. A., AbulEla, F., Nasr-Allah, A. A., Mahmoud, A. M., \& ElShemy, H. A. (2011). Eichhornia crassipes (Mart) solms From water parasite to potential medicinal remedy. Plant Signaling \& Behavior, 6, 1-3.

Bai, Y., Liang, J., Liu, R., Hu, C., \& Qu, J. (2014). Metagenomic analysis reveals microbial diversity and function in the rhizosphere soil of a constructed wetland. Environmental Technology, 35, 2521-2527.

Caldelas, C., Iglesia-Turino, S., Araus, J. L., Bort, J., \& Febrero, A. (2009). Physiological responses of Eichhornia crassipes (Mart.) Solms to the combined exposure to excess nutrients and Hg. Brazilian Journal of Plant Physiology, 21, 1-12.

Casabianca, M. L. D., Laugier, T., \& Posada, F. (1995). Petroliferous wastewater treatment with water hyacinth: experimental statement. Waste Management, 15, 651-655.

Chen, X., Chen, X. X., Wan X. W., Weng, B. Q., \& Huang, Q. (2010). Water hyacinth (Eichhornia crassipes) waste as an adsorbent for phosphorus removal from swine wastewater. Bioresource Technology, 101, 9025-9030.

Chen, W., \& Shu, H. R. (2008). Effects of fertilization on rhizosphere microorganisms of Malus hupehensis Rehd. Plant Nutrition and Fertilizer Science, 14, 328-333.

Deng, H., Ye, Z. H., \& Wong, M. H. (2004). Accumulation of lead, zinc, copper and cadmium by 12 wetland plant species thriving in metal-contaminated sites in China. Environmental Pollution, 132, 29-40.
Elsgaard, L., Petersen, S. O., \& Debosz, K. (2001). Effects and risk assessment of linear alkylbenzene sulfonates in agricultural soil. 1. Short-term effects on soil microbiology. Environmental Toxicology and Chemistry, 20, 1656-1663.

Filip, Z. (2002). International approach to assessing soil quality by ecologically-related biological parameters. Agriculture, Ecosystems \& Environment, 88, 689-712.

Fu, M. H., Jiang, L. H., Li, Y. M., Yan, G. H., Zheng, L. J., \& Peng, J. P. (2014). Identification of gene fragments related to nitrogen deficiency in Eichhornia crassipes (Pontederiaceae). Revista Biologia Tropical, 62, 1637-1648.

Gao, S., \& Pan, W. L. (1998). Wheat root growth responses to enhanced ammonium supply. Soil Science Society of America Journal, 62, 1736-1740.

Hamonts, K., Clough, T. J., Stewart, A., Clinton, P. W., Richardson, A. E., Wakelin, S. A., O'Callaghan, M., \& Condron, L. M. (2013). Effect of nitrogen and waterlogging on denitrifier gene abundance, community structure and activity in the rhizosphere of wheat. FEMS Microbiology Ecology, 83, 568-584.

Kemmitt, S. J., Wright, D., Goulding, K. W. T., \& Jones, D. L. (2006). pH regulation of carbon and nitrogen dynamics in two agricultural soils. Soil Biology \& Biochemistry, 38, 898-911.

Liljeroth, E., Bååth, E., Mathiasson, I., \& Lundborg, T. (1990). Root exudation and rhizoplane bacterial abundance of barley (Hordeum vulgare L.) in relation to nitrogen fertilization and root growth. Plant and Soil, 127, 81-89.

Liu, X. F., Huang, X. D., \& Kong, J. (2005). Effect of C, N sources and $m \mathrm{C} / m \mathrm{~N}$ ratio on the phosphate solubilization of Aspergillus niger ML2 and ML4. Journal of Shandong University, 40, 121-124.

Lu, J. B., Fu, Z. H., \& Yin, Z. Z. (2008). Performance of a water hyacinth (Eichhornia crassipes) system in the treatment of wastewater from a duck farm and the effects of using water hyacinth as duck feed. Journal of Environmental Sciences (China), 20, 513-519.

Lu, K. H., Hu, Z. Y., Liang, J. J., \& Zhu, J. Y. (2010). Characteristics of rhizosphere microbial community structure of two aquatic plants in eutrophic waters. China Environmental Science, 30, 1508-1515.

Ma, X. M., Wang, Z. Q., Wang, X. C., \& Wang, S. L. (2004). Effects of nitrogen forms on roots and $\mathrm{N}$ fertilizer efficiency of different wheat cultivars with specialized end-uses. Chinese Journal of Applied Ecology, 15, 655-658.

Ma, Z. B., Xiong, S. P., He, J. Q., \& Ma, X. M. (2008). Effects of nitrogen forms on rhizosphere microorganisms and soil enzyme activity under cultivation of 
contrasting wheat cultivars during booting and grain filling period. Acta Ecologica Sinica, 28, 1544-1551.

Marschner, P., Crowley, D., \& Yang, C. H. (2004). Development of specific rhizosphere bacterial communities in relation to plant species, nutrition and soil type. Plant and Soil, 261, 199-208.

Matsuzawai, H., Tanaka, Y., Tamaki, H., Kamagata, Y., \& Mori, K. (2010). Culture-Dependent and Independent Analyses of the Microbial Communities Inhabiting the Giant Duckweed (Spirodela polyrrhiza) Rhizoplane and Isolation of a Variety of Rarely Cultivated Organisms within the Phylum Verrucomicrobia. Microbes and Environments, 25, 302-308.

Mota, D., Faria, F., Gomes, E. A., Marriel, I. E., Paiva, E., \& Seldin, L. (2008). Bacterial and Fungal Communities in Bulk Soil and Rhizospheres of AluminumTolerant and Aluminum-Sensitive Maize (Zea mays L.) Lines Cultivated in Unlimed and Limed Cerrado Soil. Journal of Microbiology and Biotechnology, 18, 805-814.

O’Donnell, A. G., Seasman, M., Macrae, A., Waite, I., \& Davies, J. T. (2001). Plant and fertilizers as drives of changes in microbial community structure and function in soils. Plant and Soil, 232, 135-145.

Reddy, K. R., Agami, M., \& Tucker, J. C. (1989). Influence of nitrogen supply rates on growth and nutrient storage by water hyacinth (Eichhornia crassipes [Mart.] Solms) plants. Aquatic Botany, 36, 33-43.

Reddy, K. R., Agami, M., \& Tucker, J. C. (1990). Influence of phosphorus supply rates on growth and nutrient storage by water hyacinth (Eichhornia crassipes [Mart.] Solms) plants. Aquatic Botany, 37, 355-365.
Söderberg, K. H., \& Bååth, E. (2004). The influence of nitrogen fertilisation on bacterial activity in the rhizosphere of barley. Soil Biology \& Biochemistry, 36, 195-198.

Stottmeister, U., Wiessner, A., Kuschk, P., Kappelmeyer, U., Kästner, M., Bederski, O., Müller, R. A., \& Moormann, H. (2003). Effects of plants and microorganisms in constructed wetlands for wastewater treatment. Biotechnology Advances, 22, 93-117.

Su, Q., Du, C., Zheng, A. N., Wei, Y. K., Xu, H., \& Huang, X. J. (2013). Effects of Wedelia trilobata invasion on soil microorganisms and soil pH. Hubei Agricultural Sciences, 52, 2543-2546.

Tanaka, Y., Tamaki, H., Matsuzawa, H., Nigaya, M., Mori, K., \& Kamagata, Y. (2012). Microbial community analysis in the roots of aquatic plants and isolation of novel microbes including an organism of the candidate phylum OP10. Microbes and Environments, 27, 149-157.

Wu, H., \& Zheng, S. Z. (1993). Effect of root exudates from Eichhornia crassipes on phenol-degrading Enterobacter sp. nov. Chinese Journal of Applied Ecology, 4, 78-84.

Zhao, D. J., \& Zheng, S. Z. (1996). Chemotaxis of amino acids in root exudates from Eichhornia crassipes to its rhizospheric Enterobacter sp. F_2. Chinese Journal of Applied Ecology, 7, 207-212.

Zhu, H. H., Yao, Q., Long, L. K., \& Yang, S. Z. (2004). Influence of different $\mathrm{N}$ forms on spore germination and hyphal growth of AM fungus. Mycosystema, 23, 590-595. 